\title{
BIRDS OF PREY
}

IN EUROPE 


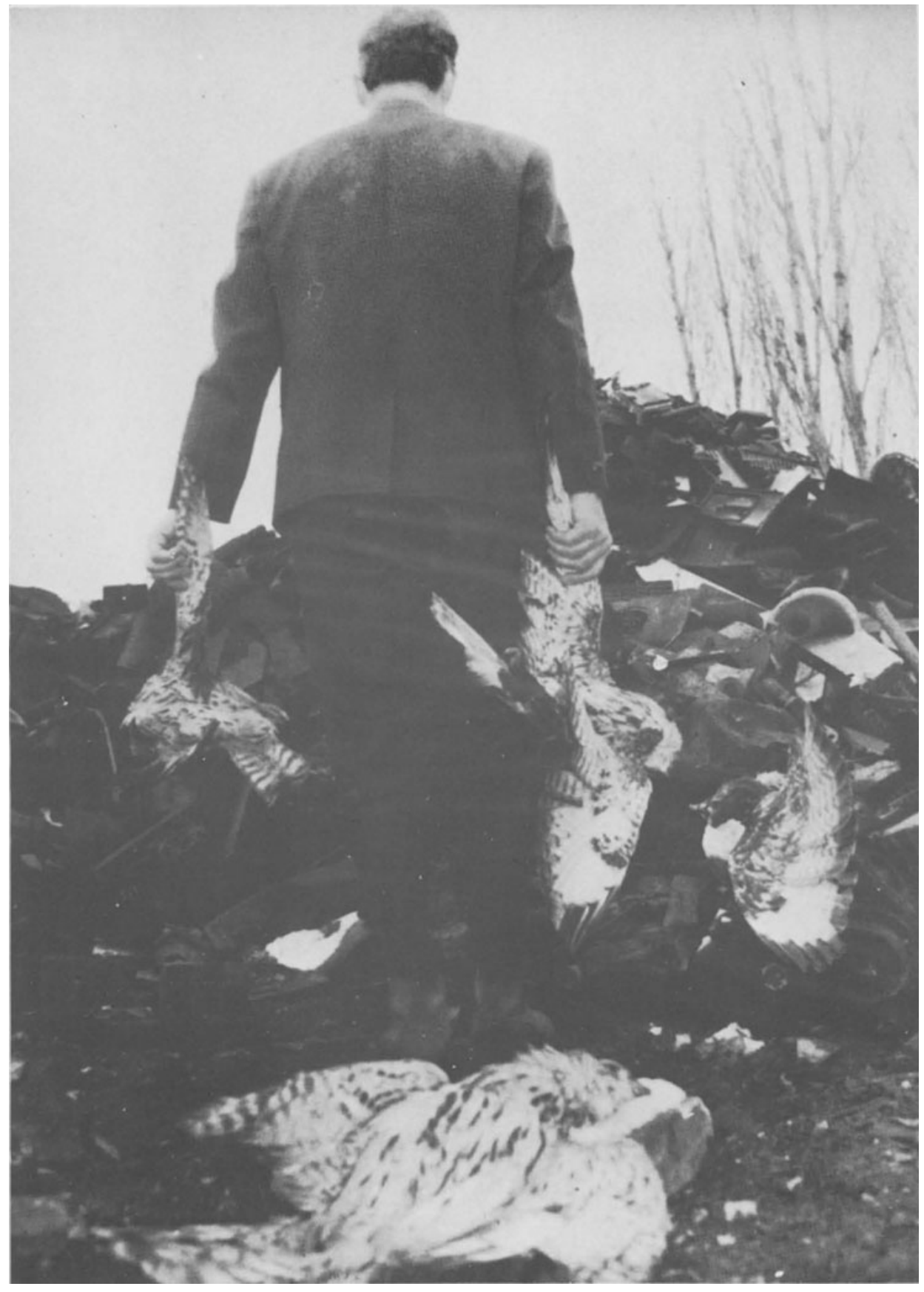

Man, his rubbish and dead birds of prey-an ignoble end 


\section{BIRDS OF PREY IN EUROPE}

MAARTEN BIJLEVELD 
(C) 1974 Maarten Bijleveld

Softcover reprint of the hardcover ist edition 1974

All rights reserved. No part of this

publication may be reproduced or transmitted,

in any form or by any means, without prior permission

\author{
Published by \\ THE MACMILLAN PRESS LTD \\ London and Basingstoke \\ Associated Companies in New York Melbourne \\ Dublin Fohannesburg and Madras
}

SBN 33373309

ISBN 978-1-349-02395-o ISBN 978-1-349-02393-6 (eBook)

DOI 10.1007/978-1-349-02393-6 
To my Parents and to Catheline 


\section{Preface}

In 1965, Professor K. H. Voous wrote: 'If I were to give my own ideas free play, I would arrive at a present population for the birds of prey in Europe amounting to $\mathrm{I} \%$ of the number still to be found in Europe 150 years ago. This percentage may even be on the high side.' The realisation that the present extreme scarcity of birds of prey in Europe represents an abnormal situation led to the investigation behind this book. As is often the case for the historian, in forming a picture of the European raptors in the last two centuries I have had to depend on meagre and incomplete data. The lacunae in our knowledge are clearly evident in the analysis of the individual species.

It is encouraging to be able to mention here that the preparation of the material for this book has already resulted in two new European projects, one concerning an attempt to save the last Sea Eagles in Schleswig-Holstein and the other the establishment of a permanent feeding place for vultures in northern Spain. It is my great hope that this study may contribute, at the eleventh hour, to finding means to preserve one of the most fascinating subjects in European nature.

It is in no sense an exaggeration to say that, without the unfailing support and encouragement of my wife and of my teacher and mentor Professor $\mathrm{K}$. H. Voous, this book would never have been completed. It would be difficult to thank them adequately. I also wish to express my gratitude to the Institute for Nature Management for making it possible for me to undertake this study, to the Netherlands Organisation for Pure Scientific Research Z.W.O. for a travel grant, to the Zoological Museum at Amsterdam and in particular to Dr Jan Wattel for the many facilities afforded me, to Dr Nora Croin Michielsen for her critical reading of the manuscript and valuable suggestions, to Mrs Inez Seeger for the translation of the text and to the Netherlands Ministry of Education who made this possible. I must thank Stanley Cramp for his help in the final editing of the manuscript and for his assistance in general which in many ways led to the publication of this book. And last, but not least, I wish to thank the many colleagues in almost all of the countries of Europe, whose names will be found in the book itself.

The manuscript itself was completed by September I97I and since that time some more recent data have been added to the text.

M. F. I. J. BIJLEVELD 


\section{Foreword}

It is a pleasure to write a foreword to what I consider to be a most remarkable book. This book is unusual in that it deals profoundly with nature conservation and yet this has not prevented it from being the thesis required for a doctor's degree in natural sciences at the Free University of Amsterdam.

There are many reasons for me to have accepted the invitation to introduce this book to conservationists, ornithologists and scientists alike. In the first place it cannot be denied that the impact of man on the geographical distribution of all kinds of animals, and birds of prey in particular, has been large to an alarming degree. Most probably man's devastating influence on nature is of a much longer standing than is generally accepted. Early civilisations must have unbalanced nature as thoroughly as human settlements do at present, and there is increasing evidence that early man, arriving in America through the Bering Strait land connection probably some 50,000 years ago and subsequently spreading over the North American continent, left behind his expanding frontier lines areas in which the rich mammalian faunas were ravaged if they had not already become extinct. Together with the multitude and variation of mammals the numerous huge carrion-eating raptors of various species, known from their fossil remains, have disappeared or declined to a dwindling rest of some 40 Condors which, jealously guarded in a remote corner of California by official and private, scientifically well-trained conservationists, must now survive on carrion and offal of cattle and sheep instead of flourishing throughout the continent on the herds of antelope and bison or the widely distributed deer of open country. Therefore the problem presented in this book is unfortunately not one which is restricted to Europe. Throughout the world nature is suffering, and, had it not been for the devotion of relatively few conservationists, scientists would no longer have the opportunity to make many a declining species the subject of their sacrosanct research and study. This may sound a little bit disparaging, but it is only recently that scientists are starting to rank among the most arduous and expert of conservationists! And I am not even sure of whether the learned writer of this book wishes to consider himself a scientist first, or rather a nature conservationist by vocation and profession.

After all this book does not contain a happy story. It deals with the decline of birds of prey in Europe. As such its careful, though in places somewhat anecdotal, documentation may seem to present a seemingly endless chain of 
cases of mass destruction born of hatred and thorough misunderstanding directed towards any creature possessing a hooked beak and sharp talons. Eagles, hawks and harriers have shared their unfortunate fate with other conspicuous predators, from weasels, stoats and foxes, to wolves and lynxes, tigers and lions, admired, feared and despised at the same time. More and more the deep-rooted feelings of animosity, if not pure hostility, towards predatory animals are gradually changing towards an understanding of the role these animals play in natural communities. Though persecuted to extinction they cannot be missed in nature without detrimental results. Still there are people, particularly among gamekeepers, sport-hunters and sheep- and cattle- breeders who wish to destroy any animal that, by its own nature, tends to feed on the same food resources as man. But is this really a legitimate reason for denying them a place on earth? It is this principal attitude towards nature, and towards the earth for that matter, that is bringing the conservation of nature and the survival of birds of prey and mammalian carnivores to the root of man's thinking about what he is expecting from the earth's future and from his own destiny. Do we have the sole and prime right of life on earth or are we expected to share the earth with fellow-creatures in the true sense of the word 'creature'?

Birds of prey and other predators are dependent on the availability of their prey species. Hence they can only occur in places where nature is providing a variety and relative abundance of various kinds of prey animals. Conversely, where birds of prey are flourishing in numbers and species, this means the presence of rich ecosystems or at least of natural communities that have not yet been thoroughly disturbed by man. This fact, as well as the ethical approach described in the previous paragraph have made birds of prey and the mammalian carnivores one of the best, if not the most delicate touchstone of human understanding and appreciation of nature and therefore the most appropriate challenge to the World Wildlife Fund and the peoples of the world. Saving the tiger from destruction and keeping eagles in the sky are more than incidental actions: they have a world-wide meaning and appeal to each of us personally.

In this technological world we have grown accustomed to the fact that eagles, hawks, vultures and harriers are uncommon, if not rare, birds. But in fact this seems to be a most 'unnatural' situation. The places on earth where birds of prey have remained numerous are constantly shrinking at an alarming rate. Still there are a few, even in Europe, but for their own sake these should not be mentioned too frequently. By extrapolation these regions may give rough indications of the amount of destruction of the raptors and of their prey. Lammergeiers ought to be numerous in the European Alps, as ought to be Sea Eagles along river courses and coasts in western Europe, and kites of whatever species in well-watered lowlands and hilly countries in the whole of western and central Europe. Golden Eagles ought to be numerous birds of 
passage in southern Scandinavia at least, as Gyr Falcons in Scandinavia and Britain. Ospreys, Goshawks, and Marsh and Hen Harriers should not have been all but vanished from the British Isles. Eagles of various species should abound throughout southeastern Europe as it was less than a century ago.

As I said before the book is a story of destruction and a testimony of human incapability and ignorance. Unfortunately, destruction of birds of prey is continuing at present on a large scale in many countries that consider themselves highly civilised. Perhaps they are, but their civilisation is man-centred and in the end this will bring destruction to the human environment, as no egotism, be it in civilisation or individual life, is apt to survive.

Habitat destruction and chemical poisoning and pollution have been lately added to our deadly weapons against nature and particularly against the most vulnerable species at the end of food-chains: birds of prey and carnivora.

It should be made clear, however, that the distribution and the expansion of birds of prey in Europe have also been subjected to influences other than man's. The distribution, abundance, and local diversity of animals is constantly changing in response to equally gradually changing climates and vegetations. The repopulation of Europe after the Last Glaciation (which ended some 9,000 years ago) is still not completed and extensions and contractions of ranges will probably continue as ever before. It will be one of the aims of the present and of future studies on European birds of prey to distinguish between direct human and other influences. One could ask for example whether the absence of the Lesser Spotted Eagle in western European lowland forest areas has been caused by man or whether it is 'natural'. The same applies to the momentarily rapidly shrinking range of the Imperial Eagle. But the Buzzard and particularly the Kestrel seem to have been favoured by the clearing of large forests and have profited from the mosaic pattern of agricultural grounds and forest patches which is so characteristic of the cultivated landscape of Europe.

Apart from the description of sad and deeply depressing case-histories, there are also promising and heart-warming events in the struggle for survival. These relate to the joint, multi-national efforts by private people devoted to the case of raptor conservation and to the coordinated work by contributors and officials of the World Wildlife Fund (WWF), the International Union for Conservation of Nature and Natural Resources (IUCN), the International Council of Bird Preservation (ICBP), and numerous local and national organisations. Had it not been for the efforts of the foundation EUREL (promoting the establishment of private nature reserves) there would have been no coordinated programme to save the last of the western European Sea Eagles in the Northwest German Lowlands severely threatened by destruction, egg-robbing and biocide poisoning. The same can be said of the now flourishing Agrupacion Navarra de Amigos de la Naturaleza which started an exemplary conservation programme including permanent feeding stations in northern 
Spain for Griffon Vultures, Lammergeiers and other large birds of prey at the moment that these were still rather numerous, and, very wisely, did not wait until it would have been (almost) too late, as so often happens in nature conservation actions. I mention these facts as I know that the author of this book has been a strong driving force for these and similar modern actions, which, by the way, are also highly necessary in other parts of Spain, Yugoslavia and Greece.

Quite recently the projects of reintroduction of species locally extinct have become the subject of thorough and, in some instances, controversial discussions. Most remarkably the enthusiasm for the reintroduction of vanished species, by setting free animals in areas where they once occurred but now have disappeared, is spreading at a what some consider alarming rate. The possibility of establishing the Sea Eagle in its former Scottish haunts by a reintroduction programme in Fair Isle seemed to me to be promising and desirable, but a recent report on the reintroduction of Eagle Owls in Western Germany by Eberhard Herrlinger (1 973) clearly shows the elaborate and cautious way in which these projects have to be carried out in order to become successful (as it has clearly been in the case of the Eagle Owl). Any reintroduction scheme, be it for the Sea Eagle, the Lammergeier, the Peregrine Falcon or the Goshawk, should be considered very carefully, particularly in view of the fact if the ecological conditions for the survival of the species are available and can be expected to continue for a long time to come.

The most recent asset of the conservation methods for birds of prey is the breeding of threatened species in captivity and the restocking of declining natural populations with the offspring produced. Interesting and promising though this may be (positive results with Eagle Owls and promising ones with some vultures and the Goshawk), it is sometimes overlooked that restocking can only be successful if the conditions that originally led to the decline of the species have been removed or at least considerably improved. At the same time there may be some concern about the numbers and the origin of the breeding stock required: it has recently been claimed that a North American breeding programme of Peregrine Falcons through artificial insemination might require an initial breeding stock of no less than 70 wild-caught birds, which may be far too heavy a drain on the dwindling populations of this rapidly vanishing species.

Thus, this book actually presents a sad story of human negligence and malignity, in addition to being a documentation of the decline and near-fall of birds of prey in Europe. Dr. Maarten Bijleveld, presently engaged by World Wildlife Fund headquarters in Switzerland, is to be congratulated on this written history of the birds of prey of Europe and thanks have to be rendered to him for his never failing enthusiasm and personal efforts towards the cause of nature conservation. Happily channelled through the World Wildlife Fund the 
generally growing appreciation for the need of international nature conservation, and the knowledge of recent methods to reach these aims, provide some reason for moderate and cautious optimism.

Karel H. Voous,

Professor in Systematic Zoology and Zoogeography at the Free University, Amsterdam, The Netherlands 


\section{Contents}

Preface

Foreword by K. H. Voous

vii

ix

Chapter I: The systematic persecution: a review of historical and more recent examples of the destruction of birds of prey in Europe

The eighteenth century: prelude

The nineteenth century: the culmination

The twentieth century: the finale I5

Chapter II: Other human influences contributing to the decline of the birds of prey in Europe

The forests

Drainage

Changes in agricultural methods

Transmission of electricity

Changes in the raising of livestock

The use of strychnine

Biocides and other poisons

Tourism

Chapter III: The pattern of the decline and the present situation

The Bosphorus region

Falsterbö

60

The Egyptian Vulture (Neophron percnopterus)

The Griffon Vulture (Gyps fulvus)

The Black Vulture (Aegypius monachus) 7 I

The Lammergeier (Gypaetus barbatus) 74

The Golden Eagle (Aquila chrysaetos) 76

The Imperial Eagle (Aquila heliaca) 82

The Lesser Spotted Eagle (Aquila pomarina) 85

The Spotted Eagle (Aquila clanga) 88

Bonelli's Eagle (Hieraaetus fasciatus) 88

The Booted Eagle (Hieraaetus pennatus) 90

The Buzzard (Buteo buteo) 92

The Rough-legged Buzzard (Buteo lagopus) 99 
xvi

The Long-legged Buzzard (Buteo rufinus) 99

The Sparrow Hawk (Accipiter nisus) 100

The Levant Sparrow Hawk (Accipiter brevipes) $\quad 107$

The Goshawk (Accipiter gentilis) 108

The Kite (Milvus milvus) I 5

The Black Kite (Milvus migrans) I 2 I

The Black-winged Kite (Elanus caeruleus) $\quad$ I27

The Sea Eagle (Haliaetus albicilla) 127

The Honey Buzzard (Pernis apivorus) 136

The Marsh Harrier (Circus aeruginosus) I4I

The Hen Harrier (Circus cyaneus) 149

The Pallid Harrier (Circus macrourus) I 53

Montagu's Harrier (Circus pygargus) I 54

The Short-toed Eagle (Circaetus gallicus) I59

The Osprey (Pandion haliaetus) I 163

The Hobby (Falco subbuteo) $\quad 169$

The Peregrine (Falco peregrinus) $\quad$ I75

The Lanner Falcon (Falco biarmicus) $\quad$ I 86

The Saker Falcon (Falco cherrug) $\quad$ I87

The Gyr Falcon (Falco rusticolus) $\quad$ I88

Eleonora's Falcon (Falco eleonorae) $\quad$ I90

The Merlin (Falco columbarius) 190

The Red-footed Falcon (Falco vespertinus) 192

The Lesser Kestrel (Falco naumanni) 193

The Kestrel (Falco tinnunculus) $\quad$ I95

Chapter IV: Legislation in Europe affecting birds of prey 202

$\begin{array}{ll}\text { Iceland } & 202\end{array}$

Norway $\quad 202$

Sweden 203

Finland 203

Denmark 204

Ireland $\quad 205$

Great Britain $\quad 205$

The Netherlands $\quad 205$

Belgium $\quad 205$

Luxembourg $\quad 206$

West Germany 206

East Germany $\quad 207$

France $\quad 207$

Spain $\quad 208$

Portugal $\quad 208$ 
Switzerland

Italy

Austria

210

Poland

210

Russia

2 I I

Czechoslovakia

2I I

Hungary

212

Yugoslavia

212

Greece

212

Bulgaria

213

Roumania

213

Chapter V: The preservation of the birds of prey and their future

Examples of practical measures for the preservation of birds of prey in Europe

Considerations concerning a coordinated European effort for the preservation of the birds of prey Prognosis 